\title{
The Effects of American Policies - a new classical interpretaton ${ }^{1}$
}

\author{
Patrick Minford
}

\section{Introduction}

The object of this article is to investigate the effects of US fiscal and monetary shocks on the world economy within a world macroeconomic model.

US policies over the past five years have been the object of admiration and vilification, exposition and caricature, both in the US itself and perhaps even more so in Europe. Some have argued that tight money and high deficits would not affect real interest rates or anything much except the rate of inflation and private saving. Others have argued that they would make recovery impossible by driving real interest rates to unheard of levels. Yet others have argued that the high deficits have stimulated the world economy in a 'locomotive' manner. Established forecasters' reputations have been dented while some outsiders in the US forecasting game have scored hits (notably, recently, monetarists and supply siders). Confusion reigns supreme, even over the ground rules of this discussion. The one common factor is the passionate intensity with which all views are held; the combination of Ronald Reagan and Paul Volcker has fired passions across the intellectual and political spectrum (and probably raised significantly the price of economists' services - it's an ill wind ...).

It is my contention that the effects of US policies cannot be understood in a US context alone; a closedeconomy model will not do. I will be arguing that 'crowding out' is occurring on a world scale and that the 'injured parties' are outside the US in the main; furthermore, the scale of financing required for the US deficit has only been feasible through the world capital market.

This points to an understanding of a linked economic system. How could this be achieved? Some espouse methods which locate the sources of world business cycle shocks and the nature of their persistence

\footnotetext{
This article draws on a longer paper of the same title, on which I recently gave a seminar at the IDS.
}

empirically without the specification of a structural model. ${ }^{2}$ By its nature this type of work - while it has valuable uses - cannot identify structural relationships; therefore, one cannot easily interpret the results in terms of casual mechanisms.

One method of explanation appears to be available. One can set out a causal (or 'structural') system purporting to describe the linked economies; one can ask what effects this indicates for US policies and then check whether that set of effects appears broadly to have occurred in fact. This is the method I adopt in this paper.

In brief, I shall be using a description which relies importantly on two key features - rational expectations $^{3}$ and wealth effects of government bonds. ${ }^{4}$ This description is parameterised (specified empirically), as far as possible, using estimates of postwar behaviour (some re-estimates of our own, some $a$ priori impositions, some previous work). The

\footnotetext{
${ }^{2}$ See Saidi and Huber [1983], who use vector-autoregressive methods. The standard econometric approach to model building proceeds by building a structural model and empirically testing for its statistical significance. The vector-autoregressive method seeks to identify empirically the lag structure of economic variables as they move through time without specifying the structure of the model [eds].

3 Rational expectations are based on the assumption that all economic agents formulate their expectations about future economic behaviour rationally. This information is utilised in the most efficient way possible, being incorporated into a model of the economy which is believed to describe accurately the way in which the economy operates. The most stark conclusion of the rational expectations hypothesis is that governments are unable to pursue effective counter-cyclical macroeconomic stabilisation policies as suggested by Keynes. For an accessible Keynesian introduction to rational expectations, see Shaw [1984]. Rational expectations are made operational in this paper through the assumption that the model's forecasts are the expectations [eds].

4 Wealth effects arise from the effects which changes in the net wealth of economic agents may have on consumption, savings and investment decisions. Thus, if a fall in the rate of interest leads to a rise in the price of government bonds, and if this is regarded as an increase in net wealth by government bond holders, then such agents may increase, for example, consumption expenditure out of current income [eds].
} 
description yields a clear 'story' of the effects of' monttary shocks and (bond-financed) fiscal shocks; in spite of the 'largeness' of the model, because the model is constructed according to a very clear set of theoretical restrictions and it can theretore be simply understood - the number of equations is not a measure of intellectual complexity. Finally, I shall argue that the story fits the recent live-year episode rather plausibly, reconciling many of the details whose coincidence has appeared so baffling to different schools of interpretation.

Before going any further, a brief defence of the two main features would be wise. Rational expectations I regard as the analogue of routinely-assumed optimising behaviour in the information field, it is an 'as-if assumption with the same status as the "profitmaximising' or 'utility-maximising' assumptions we make about firms and consumers. It yields strong predictions and we have good reason to believe that competitive pressures exist in the real world driving people towards this norm of behaviour.

Wealth effects of government bonds have been carefully analysed by Barro [1974], to whom is due the revival among economists of the Ricardian equivalence theorem. ${ }^{5}$ As Barro notes, there are two main reasons why bonds could be net wealth to rational agents. The first occurs it the agent leaves no bequest. The second occurs if the income tax system is progressive in effect insuring against income shocks; in this case higher future taxes will fall more on those with income good fortune than on the unlucky, and risk-averse agents will discount the tax stream to below the present value of the bonds. Empirical work to date has tended to support the view that bonds are net wealth (but not 100 per cent net wealth) in line with these two aspects. These points are discussed further in Minford and Peel [1983].

I now proceed to describe the model and so the nature of my explanation of recent events. Then I discuss the simulations of US policy. Finally, I review recent events and draw some tentative policy implications.

\section{The Liverpool International Transmission Model}

The model is macroeconomic in the sense that it has no 'supply-side' at this stage, the equilibrium (or 'natural') values of output, real interest rates, real exchange rates, etc., are taken as exogenous.

\footnotetext{
" The Ricardian equivalence theorem states that the readjustment of taxes through time with accommodating changes in the stock of government funds will leave net wealth, and therefore consumption out of current income, unchanged. Barro [1974] elucidates the assumptions necessary for this to be the case, and hence, when these assumptions do not hold, shows some of the circumstances under which there will be a net wealth effect when the government issues bonds [eds]
}

The essence of our approach is fairly simple. We have linked together nine annual country models of identical structure, and added equations for the trade (only) of other countries, divided into three blocks. Hence the interesting detail relates primarily to the nine (major OECD) countries.

Each country model has the structure set out in Minford [1980], to which the reader is referred for detailed support of the following account. The model consists of:

a) an interrelated set of private sector demands for stocks of money, government bonds (and net foreign assets), and durable goods, and for a flow of nondurable consumption goods; these demands depend on wealth and real returns;

b) a government supply function of (narrow Ml) moncy which together with the government and foreign sector budget constraints determincs also the supply of bonds plus foreign assets;

c) efficient financial markets in the operational sense that expected returns are equated across domestic and international financial assets;

d) rational expectations which are implemented operationally by using the model's forecasts as the expectations;

e) the supply of output is modelled via a price equation derived from an aggregate production lunction as a mark-up over costs which varies with the level of output;

f) the labour market has a significantly large union sector; the non-union sector clears continuously (at levels heavily influenced by social security benefits). But the union's real wage target is seen as the outcome of intertemporal maximisation of their members' incomes and, given adjustment costs in firms' demand for labour, this gives rise to a union real wage which is a mark-up over expected non-union real wages and also dependent on lagged union real wages and firms' other cost factors. This real wage target is translated into a one-year nominal wage contract on the basis of expected inflation. Aggregating together union and non-union wages and substituting out firms' demand for labour, we obtain a reduced form real wage equation positively related to output, lagged real wages and employer taxes on labour and negatively to unexpected inflation, benefits and employee taxes. Hence if there is unanticipated inflation, real wages fall, and so do output costs, the supply curve of output theretore shifts outwards temporarily. In subsequent periods, real wages gradually return to equilibrium and output with it. ${ }^{6}$

g) the current account external balance depends on the real exchange rate (defined as domestic relative to foreign consumer prices adjusted for the exchange

\footnotetext{
6 This is a Lucas-type supply function which is however derived by a rather different route from that chosen by Lucas and Rapping [1969].
} 
rate) and domestic and foreign 'absorption' (total final expenditure).

Hence the model's features are predominantly 'New Classical'. These features distinguish it from available multi-country models such as Project Link, which tend to be very large, preserve a traditional Keynesian approach, and contain a large number of auxiliary hypotheses besides their Keynesian core. Variation in the auxiliary hypotheses makes it easy for these models to rationalise events ex post without jettisoning that core; but this procedure implies that little of any interest is being tested in prediction.

From an academic viewpoint our aim is to minimise the number of auxiliary hypotheses and so make it possible to test morc effectively the core new classical hypothests. Ideally, we would want to set up a 'Keynesian' alternative model with a minimum of auxiliary hypotheses, to compare with ours. However, at present this lies outside our capability.

The problem much stressed recently in model-building has been the 'Lucas critique', i.e. that model parameters may change when policies and other parameters of the exogenous environment change. In principle we can avoid this problem by specifying all expectations (and any relevant higher moments) explicitly. In practice, however, so many enter a model such as this that modelling economy enforces some choice of critical expectations to model explicitly, leaving others to be implicit and so vulnerable to the critique. Empirical trials should tell us how well our choices have been made and whether it would pay us to widen the choice; this is, however, in the nature of empirical work and does not pose a deep-seated challenge to our methods.

The model is based on preliminary econometric estimates using limited information methods. ${ }^{7}$ Some parameters have bcen imposed on the basis of previous work, when satisfactory estimates could not be obtained. Full dynamic simulation tests have not yet been possible. Therefore, viewed empirically the model is as yet a tentative, essentially untested construct. Nevertheless, in so far as its structure reflects a major strand of modern macrocconomic thinking and its parameters are related to available empirical work, its simulation properties are of interest.

\footnotetext{
Econometric estimation of structural cquations of an economic model must take into account the simulaneous determination of the systen in order to climate estimation bias. Limited information methods, as the title implies, utilise incompletc information about the simultaneous system, taking into account the variables which enter the rest of the model but not the full specification of the other equations in the model. Other simulaneous estimation methods, such as threc-stage least squares and Full Information Maximum I.ikclihood, do take into account the full specification of the moctel when individual equations are estimated [eds].
}

\section{The Full World Model}

This is a very large model for rational expectations solution. There are 160 equations and 45 expectational variables. Experiences of estimating and solving the UK model, which is just over one tenth the size but is by now fully operative in forecasting and policy analysis, has taught us that the coefficients used must be tightly circumscribed by prior restrictions if the model is to be capable of generating a 'proper' solution - i.e. One that lies within a plausible distance from the equilibrium path. The coefficients that give most trouble in this respect are the wealth coefficients; at this stage we have been unable to find a specification within which frec estimation of these gives proper solutions. These coefficients are largely imposed therefore in the current version, at values that imply small impact effects (as assumed in our previous formal discussion).

The annual data, at the level of aggregation we were using failed also to generatc sensible current account balance equations. The coefficients of these have accordingly been taken from Beenstock and Minford [1976], who estimated a comprehensive set of trade elasticities of plausible size on a consistent basis. The long-run elasticities on 'competitiveness', which were estimated via polynominal distributed lags of long duration (up to six years) have been applied here to the expected deviation from purchasing power parity over the five years ahead, rather than the lagged values of this deviation. ${ }^{8}$

Otherwise the coefficients are freely estimated subject to these imposed values. (A listing is a vailable from the author for the equations with their descriptive statistics, and detailed data and methods.) It must be stressed that the current version is very much an interim working version, a primitive monster which we hope will evolve to a better adapted form. To examine the model's properties, we focus on two simulations only, albeit important ones, US fiscal and monetary expansionary surprises.

\section{US Policy Simulations with the Full Model A once-for-all rise in the US money supply}

We begin with that simulation standby - a monetary shock, i.e. an unanticipated once-for-all rise in the money supply. Table 1 shows the signs of the full model impact effects.

\footnotetext{
"Changes in economic variables mav takc varying amounts of time before their full cftects are felt, so that the lagged values of these variables often appear in conometric models. Polvnomial distributed lags assume that the distribution of the lag has a polynomial form in which the squared and higher order teams enter [cds].
} 
Table 1

Impact effects of US monetary and fiscal shocks

\begin{tabular}{|c|c|c|}
\hline & $\begin{array}{l}\text { monetary } \\
\text { expansion } \\
\text { shock }\end{array}$ & $\begin{array}{c}\text { fiscal } \\
\text { expansion } \\
\text { shock }\end{array}$ \\
\hline domestic prices & + & - \\
\hline foreign prices & + & + \\
\hline $\begin{array}{l}\text { real exchange } \\
\text { rate }\end{array}$ & $+/ 0$ & + \\
\hline $\begin{array}{l}\text { domestic real } \\
\text { interest rate }\end{array}$ & - & + \\
\hline $\begin{array}{l}\text { foreign real } \\
\text { interest rate }\end{array}$ & - & + \\
\hline domestic output & + & $-/ 0$ \\
\hline foreign output & + & $-/ 0$ \\
\hline
\end{tabular}

The one sign that is counter-intuitive is on the US real exchange rate. This rises, instead of falling as one might expect. The reason turns out to be simple enough. There is a powerful real interest rate effect in the model. As world real interest rates fall, the US demand increases substantially; this exceeds the rise in supply. But in the rest of the world, the rise in demand is less thant the rise in supply. Hence the relative price of US goods (the real exchange rate) rises, that of goods elsewhere falls.

The particular sign effect may well be a quirk of relative elasticities, wealth in particular. It cannot be regarded as robust at this stage. But it is at least interesting that it should be thrown up by our parameter values.

At the world level, the simulation offers no real puzzles. Output expands because there is an unexpected rise in prices. Once this has occurred, producers gradually return output to normal.

We now turn to the numbers produced by a two per cent once-for-all money supply increase. Figure 1 shows selected effects on output, real interest rates, prices and the real exchange rates. The basic flavour of the simulation is given by this diagram. World output rises by $1 \frac{1}{2}$ per cent (US by nearly two per cent) on impact - a large effect for only a two per cent money supply increase. World (and US) real interest rates fall one per cent at the long end, but (rather puzzlingly) a lot less at the short end. World and US prices rise, as does the US real exchange rate (while others fall on average).
These are the impact effects. The dynamic path back to equilibrium turns out (rather unusually among the simulations) to have a strong cyclical component and a tendency to converge (monotonically) at around 25 per cent each period (six and a half years to get within 15 per cent of equilibrium).

\section{US fiscal expansion}

We study next a temporary rise (for one year only) in the US budget deficit - financed by bonds (i.e. the money supply is held constant). The impact effects in the model are shown in Table 1. The counter-intuitive result is that the output in the US and abroad falls instead of rising as conventional theories would indicate. The model also shows that US prices definitely fall.

The unusual effect on output across the world can be explained thus: the fiscal expansion raises real interest rates, conventionally enough as demand for goods increases; the rise in interest rates also lowers demand for money but the rise in bonds (and so wealth) associated with the higher deficit more than offsets this effect on money demand, so that the net effect is to increase money demand, lowering prices for given output. Output therefore falls because of the unexpected fall in prices.

This is none other than the result first introduced by Blinder and Solow [1973], whereby wealth effects of bond financing may be greater on money demand than on demand for goods, so that more than 100 per cent crowding out occurs. (They associated this result with instability, but that does not occur in a rational expectations context.)

The actual numbers are illustrated for a few main variables in Figure 2, for a one-year rise in the US deficit of about one per cent of US GDP. It can be seen that there is a contraction on impact both on world and US GDP. There is also a sizeable contraction

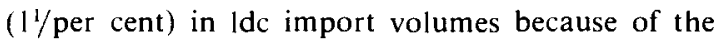
effect on their debt interest of higher world real interest rates. These real rates in turn rise by nearly one per cent at the long end and about $1 \frac{1}{2}$ per cent at the short end. This is a substantial effect and it can be seen that international crowding out (especially of ldcs) is fairly significant.

The US real exchange rate appreciates by nearly one per cent: about the same as the US real long rate of interest. When one reflects that the actual US budget deficit has risen from one per cent of GDP in 1978 to three per cent in 1980 and 1981, five per cent in 1982 and six per cent in 1983, and that at present there is no viable plan to reduce it, the scale of the effect on world real interest rates and on the US real exchange rate of 
Figure 1

US money expansion by 2 per cent (once for all)

$\%$ pa

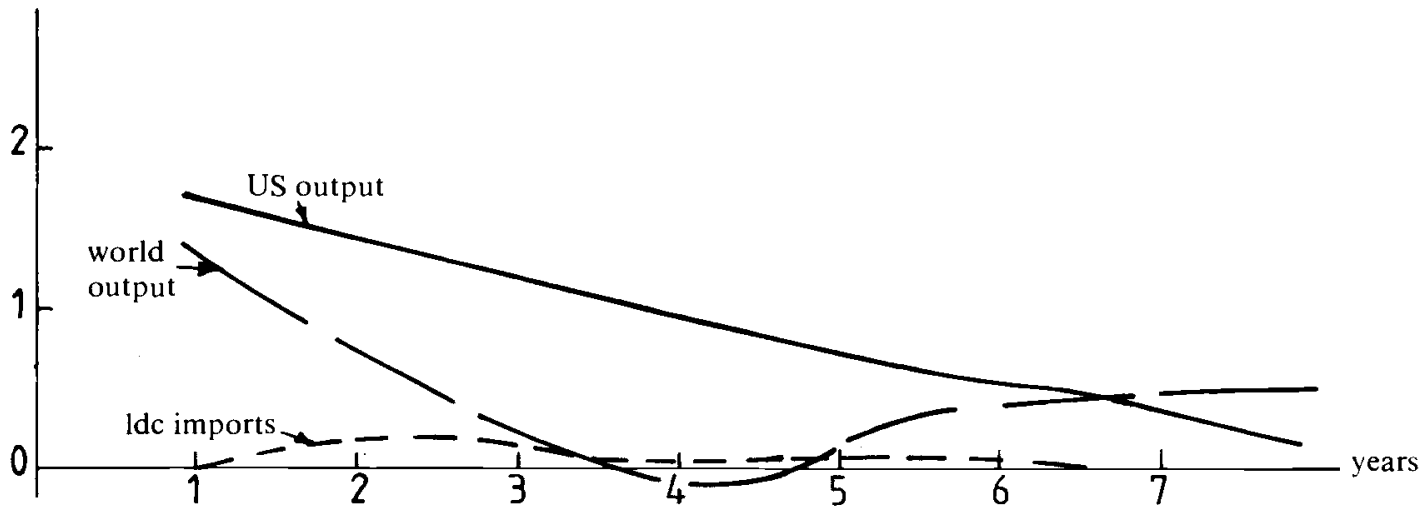

$\% \mathrm{pa}$

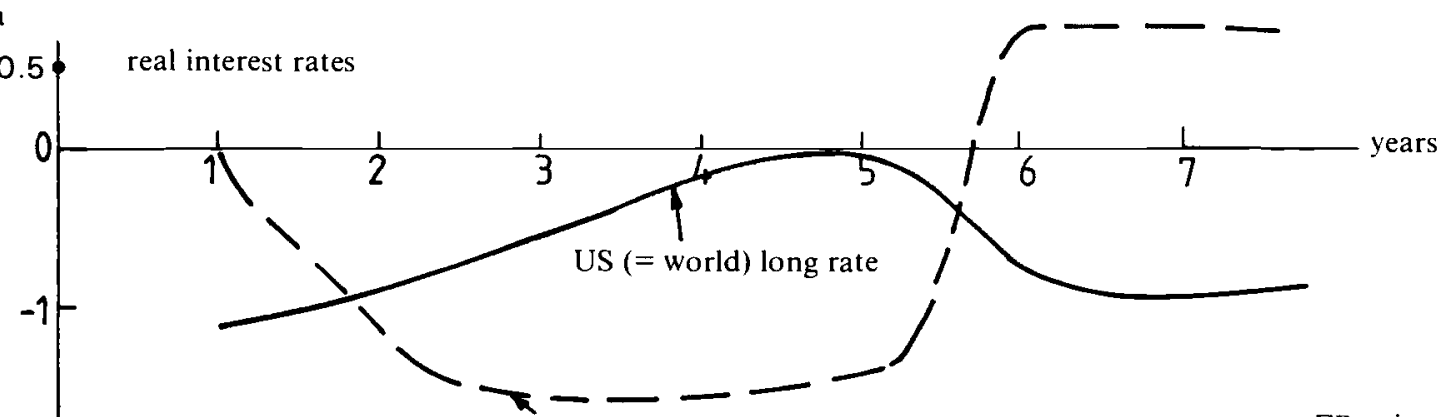

US ( = world) short rate

$\%$ pa 35 real exchange rates, prices

(USA, France)

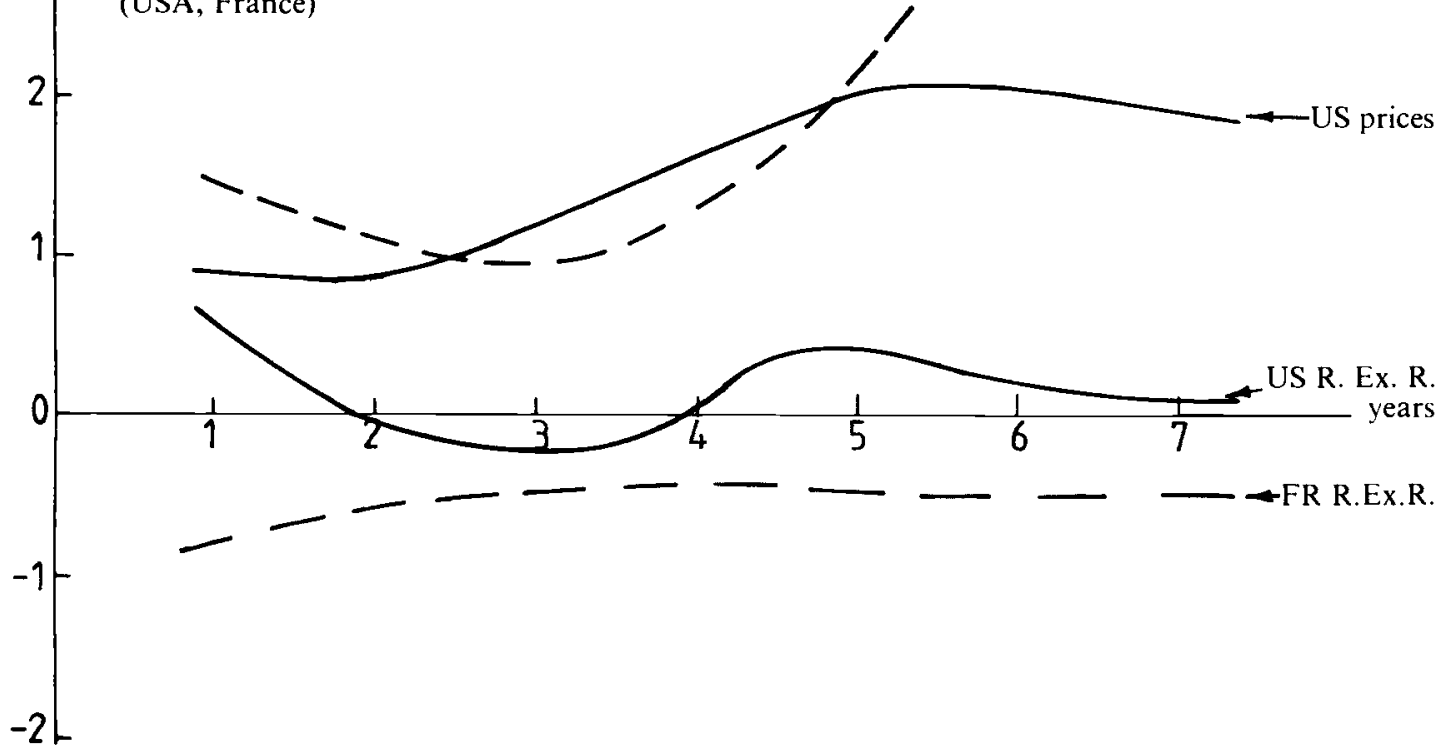


Figure 2

US deficit rise (by 1 per cent of GDP, for one year only)

$\%$ pa world output

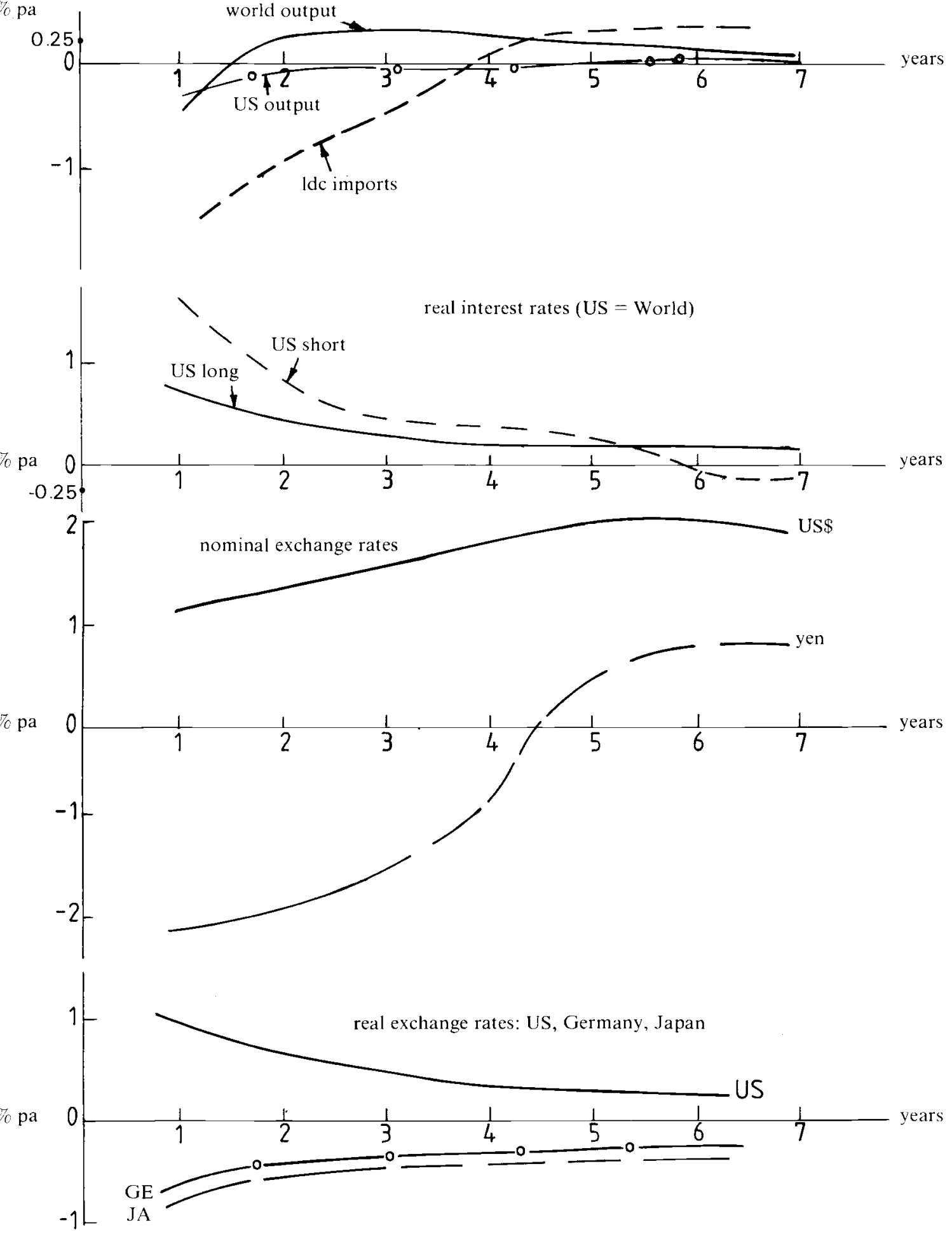


recent US fiscal policies is suggested - approximately six times the impact effects of this simulation. Being a longer-lasting fiscal change, these effects would last correspondingly longer - in fact in a simulation of the same shock lasting five years, real world interest rates stayed up at over one per cent higher for nine years.

When we turn to the dynamic path on this temporary shock, there is little cyclical component. Convergence (monotonic again) is a bit more rapid than in the monetary shock case - about 30 per cent per year. The recovery of world output in year two reflects the fact that there is a strong shock-adjustment effect of higher real interest rates; in ycar two this 'unwinds' giving rise to the moving average process discussed earlicr.

To sum up, this fiscal simulation indicates that US fiscal expansion does not 'stimulate' the world or the US economy but mainly causes higher world real interest rates and a US real appreciation. The crowding-out that results from higher real interest rates has a particular impact on lde's and other major debtors.

\section{Recent Events and Policy Implications}

Based on these simulations, we can hazard an outline of the reasons for the 1980-82 world recession and the 1983 recovery; we have not yet been able to use the model formally to track these events but an informal discussion is possible.

The salient features of the world economy since 1978 can be crudely summarised. World out put fell between 1979 and 1982 in a prolonged 'double-bottomed" recession. It then began - at the end of 1982 - a fairly normal recovery, rapid (as typically occurs) in the US and sluggish elsewhere (except for the UK whose recovery began, like its recession, carlicr than most and had gathered some strength by end-1982). World real interest rates, having been very low for most of the 1970s, rosc sharply in 1980 and have remained high ever since. Inflation rose to a peak in 1980 of over 10 per ccnt and has since then fallen rapidly, reaching three per cent in the US in 1983 and $4 \frac{1}{2}$ per cent in the world.

On the policy side, the US deficit has grown substantially as a fraction of GDP; allowing for plausible 'cyclical adjustment' does not change that picture. If one takes at face value thc determination of the Federal Reserve Board to hold inflation at three per cent or so, then given that the deficit is bcing financed by nominal bonds of average maturity, '(prospective) inflation accounting' does not change the picture significantly cither. From the rational expectations view point, we need to know how much of this deficit change was unanticipated; my suggestion would be that it was unanticipated in 1979 but that by the end of 1980 the expectation of sustained high deficits under Reagan's policies had become dominant.

US monetary growth, which is essentially independent of the President in the USA, began to be curbed in 1980 when it fell to 8.6 per ecent. This has to be seen against a rise in inflation to 13.5 per cent (we can think of inflation as reflecting largely the expected monctary growth in the previous year). It would have becn reasonable to expect the Fed to allow much fastcr M 1 growth given the 'nceds of trade'. Hence I would suggest that there was a substantial unexpected fall in Ml growth. In 1981, M1 growth fell further to 5.1 per cent; again inflation at 10.4 per cent in 1981 suggests that much of this fall was unanticipated. 1he same, but to a lesser extent, was true of 1982 (the low avcrage M1 figure conceals a very low figure early in the year but a much higher figure in the sccond half). Thus there may have been three successive negative monetary shocks in a row. The 1983 figure by contrast indicates a strong positive monetary shock, Ml may have grown by $7 \frac{1}{2}$ per cent against inflation of three per cent.

According to this interpretation, the rise in world real interest rates in 1980 was the result of the rise in the US deficit and the unexpected fall in US MI growth. That world real rates have stayed so high and appear set to continue that way is due to the sustained high deficits (for negative monetary shocks gave way to a positive shock in 1983).

The pattern of growth is to be explained not at all by fiscal shifts; these were positive in 1980 (and again in 1982 ) but did not prevent recession in 1980 and continued recession in 1982. Indeed according to the model they may have somewhat worsened the recession (partly by precipitating the ldc debt crisis).

Rather, the recession, its 'double-bottom' and long duration, are plainly due to the succession of negative monetary shocks, inspired in turn by the Fed's determination to get inflation back down to rates last seen in the 1960s. The recovery process would have occurred anyway in 1983 according to the model, provided there was no further negative shock then. It has, however, been speeded up by a fairly strong positive monetary shock (related, it scems, to the Fed's fears for the collapse of the international monetary system under a major default).

Last, the inflation story can be interpreted as the successive downgearing of expected monetary growth, as the Fed's determination and stamina progressively became apparent. In the US there were no announcements of long-term targets, only one-year ones; this lack of long-term commitments was 
Recent world events

\begin{tabular}{|c|c|c|c|c|c|c|}
\hline & 1978 & 1979 & 1980 & 1981 & 1982 & 1983 \\
\hline \multicolumn{7}{|l|}{ Growth in GDP } \\
\hline US & 4.7 & 2.4 & -0.3 & 2.6 & -1.9 & 3.4 \\
\hline OECD & 3.9 & 3.2 & 1.2 & 2.0 & -0.5 & 2.2 \\
\hline \multicolumn{7}{|l|}{ Inflation (CPI) } \\
\hline US & 7.6 & 11.3 & 13.5 & 10.4 & 6.2 & 3.2 \\
\hline Industrial countries & 7.2 & 9.1 & 11.9 & 9.9 & 7.5 & 5.1 \\
\hline \multicolumn{7}{|l|}{ Real short-term ${ }^{1}$ interest rates } \\
\hline US & -0.4 & -1.3 & -1.9 & 3.7 & 4.5 & 5.9 \\
\hline \multicolumn{7}{|l|}{ Fiscal and monet ary policies } \\
\hline $\begin{array}{l}\text { US federal deficit (calendar year) as \% } \\
\text { of US GNP }\end{array}$ & 1.7 & 1.1 & 2.6 & 2.7 & 4.9 & 7.0 \\
\hline US growth in $\mathrm{Ml}^{2}$ & 7.3 & 7.6 & 8.6 & 5.1 & 4.8 & 9.0 \\
\hline Industries countries growth in $\mathrm{M}^{2}$ & 10.8 & 9.6 & 6.5 & 6.0 & 6.7 & 9.5 \\
\hline
\end{tabular}

'Treasury Bill Rate (3 months) minus average inflation rate (this assumes that over such a short time horizon expected and actual inflation are equal, probably not a bad approximation).

${ }^{2}$ IFS definition

encouraged by the political system - for example, mid-term elections to Congress and the Fed Chairman, Paul Volcker's own reappointment date in 1983 - but it no doubt partly contributed to the downward-ratchet pattern of expectations.

A 'sharp enduring shock' administered in 1980 and backed by a complete political commitment would, if possible - according to the model - have precipitated a bigger recession in 1980 (it was actually quite mild) but one that would have ended more quickly and brought inflation down more rapidly.

In view of the propensity for many economists to cite 'oil factors' as major casual agents over this period, I should stress that it enters the story here not at all. Oil is 'just another input commodity' in this model; its price is a relative price and energy technology is just one source of technological change. Clearly, shocks to tastes and technology matter at the micro level and if sufficiently correlated across industries may matter at the business cycle level. I feel free to refer to such correlated shocks as sources of macro shock; but in this recent episode there is no compelling reason to do so.

Should US fiscal policy have moved 'in line' with tight money? This has been the main flashpoint of recent
US-rest of world policy interchange. The rest of the world has not welcomed the effect of US government borrowing in pushing up real interest rates worldwide. (The logic of tight money has separately been accepted as necessary for anti-inflation policy.) This complaint, in the light of the model's interpretation, has two dimensions. First, there is the dislike of shocks in themselves; uncertainty is increased - a stable fiscal policy is to be preferred to an unstable one. Second, in so far as the rest of the world is a net debtor to the US (which it is), ${ }^{9}$ it suffers a rise in its real debt burden; there is therefore a transfer effect.

Secondly, shocks are as unwelcome in the US as elsewhere; the fact that a new government felt it necessary to impose one reveals its judgement that the need offset the unwelcome effects. Governments, like private agents, optimise in response to changed circumstances. One can only speculate on whether it was truly in the US interest for taxes to be deferred in this way; the optimal tax pattern over time is discussed in Barro [1974], who argues from the transactions costs of changing tax rates that they should be constant. If this is so, then the issue revolves around whether government spending projections are for such

\footnotetext{
${ }^{9}$ Net overseas assets of the US banking system at end-1981 were about $£ 138$ bn.
} 
falls that future tax rates will fall, making it suboptimal to raise them now.

As far as transfer effects are concerned, such possibilities are inherent in the signing of debt with short-term maturities; the debt was voluntary so no complaint is possible. Nevertheless, a severe transfer effect on ldes has turned out to be particularly disruptive - and has forced a shift in US monetary policy to avoid monetary collapse. In its own interest, the US needs to take these effects into account, legitimate as it is to cause them.

A few things the model does imply are:

a) the more predictability in government policy the better; shocks and uncertainty cause costs. Therefore, if the US shift to higher deficits was not internally justified, it imposed costs on the world by disturbing plans and in particular raised the variance of output;

b) planned 'reflation' or 'locomotive' policies will have their principal effects on inflation and, if fiscal and bond-financed, on real interest rates; they will not speed up recovery or end recession;

c) there are a number of ways in which international feedback rules for monetary and fiscal policy could 'work' to reduce the variance of world output [see Minford and Peel 1983]; but it is not at all obvious what values should be given to the feedback coefficients to improve the stability of the model relative to its present tolerable level (convergence at 30 per cent p.a.).

d) governments also can optimise individually with respect to world capital market conditions by borrowing less at times of high real interest rates; if they do, the response of world real rates to higher US borrowing would of course be smaller and so too would the disturbance to world output.
To sum up, with respect to US policies, the rest of the world does not appear to have a case for them to change, other than to point out the effects which the US authorities may not have taken into account in designing them. A world government might take a different view of what US policy should be; but then we do not have one - and if we did, the rest of the world would not be free either!

\section{References}

Barro, R. J., 1974, 'Are government bonds net wealth?', Journal of Political Economy'

Beenstock, M. and A. P. L. Minford, 1976, 'A quarterly econometric model of work trade and prices, 1955-71' in M. Parkin and G. Zis [eds], Inflation in Open Economies, Manchester University Press

Blinder, A. and R. Solow, 1973, 'Does fiscal policy matter?', Journal of Public Economics, vol 2, pp319-37

Lucas, R. and L. Rapping, 1969, 'Real wages, employment and inflation', Journal of Political Economy

Minford, A. P. L., 1980, 'A rational expectations model of the United Kingdom under fixed and floating exchange rates' in K. Brunner and A. H. Meltzer [eds], On the State of Macro Economics, Carnegie Rochester Conference Series on Public Policy no 12, supplement 2, Journal of Monetary Economics

Minford, A. P. L. and D. A. Peel, 1983, Rational Expectations and the New Macroeconomics, Martin Robertson, Oxford

Saidi, N. and G. Huber, 1983, 'Postwar business cycles and exchange rate regimes: issues and evidence', University of Geneva, paper presented to 1983 Konstanz Seminar on Monetary Theory and Monetary Policy, mimeo

Shaw, G. K., 1984, Rational Expectations: an Elementary Exposition, Wheatsheaf, Brighton 